\title{
Pengaruh Latihan Plyometric Cone Hop With 180-Degree Turn, Lateral Jump Over Barrier, Lateral Cone Hops Terhadap Peningkatan Power Otot Tungkai Dan Kelincahan
}

\author{
Syawal Hari Hidayatullah ${ }^{1}$, Andun Sudijandoko², Fransisca Januarumi Marhaendra Wijaya ${ }^{3}$ \\ Program Studi Pendidikan Olahraga Pascasarjana Universitas Negeri Surabaya \\ Email: syawalharihidayat@gmail.com
}

\begin{abstract}
Abstrak: Penelitian ini bertujuan untuk menganalisis: pengaruh latihan Cone Hop with 180Degree Turn, Lateral Jump Over Barrier, Lateral Cone Hops terhadap peningkatan power otot tungkai dan kelincahan; dan seberapa besar perbedaan pengaruh latihan Cone Hop With 180-Degree Turn, Lateral Jump Over Barrier, Lateral Cone Hops terhadap peningkatan power otot tungkai dan kelincahan. Metode penelitian ini ialah kuantitatif jenis Eksperimen Semu dengan rancangan matching only design. Subjek penelitian yaitu 40 siswa putra kelas XI SMA 1 Batuan Sumenep yang terpilih sesuai kriteria tertentu. Data dianalisis menggunakan Paired t-test dan Multivariate analysis of variance (MANOVA) pada SPSS 22.0. Pengambilan data menggunakan tes Power otot tungkai Standing Broad jump dan tes AFL Agility. Hasil penelitian menunjukkan peningkatan power otot tungkai dan kelincahan pada kelompok yang diberikan treatment (Sig. Kurang dari 0,05) pada uji Paired t-test. Peningkatan power otot tungkai terjadi pada kelompok cone hop with 180-degree turn $17 \%$ dan kelincahan $11 \%$, latihan Lateral jump over barrier 5\% peningkatan power otot tungkai dan $6 \%$ kelincahan, dan peningkatan power otot tungkai $10 \%$ dan $8 \%$ peningkatan kelincahan latihan Lateral cone hops. Hasil uji Manova menunjukkan latihan Cone hop with 180-Degree Turn memiliki perbedaan rata-rata lebih besar dibanding kelompok lainnya.
\end{abstract}

Kata Kunci : Latihan; Cone Hop With 180 Degree Turn; Lateral Jump Over Barrier; Lateral Cone Hops; Power; Kelincahan.

\section{PENDAHULUAN}

Kesehatan merupakan kebutuhan penting bagi manusia, karena aktivitas manusia dalam menjalani kehidupan seharihari membutuhkan kualitas fisik yang sehat dan bugar. Aktivitas olahraga merupakan solusi bagi manusia untuk mendapatkan kesehatan. Pendidikan formal juga menekankan pentingnya kebugaran jasmani melalui aktivitas gerak dan pembelajaran pendidikan jasmani dan olahraga. Aktivitas sehari-hari seperti bekerja, belajar, dan aktivitas rumah tangga sangat membutuhkan kebugaran fisik untuk melakukannya. Pentingnya kebugaran jasmani bisa mempengaruhi gerak dan konsentrasi pada manusia, terutama pada saat belajar, bekerja yang membutuhkan konsentrasi tinggi. Dalam kehidupan sehari-hari kebugaran seseorang (siswa, mahasiswa, karyawan, pekerja, dll) tentunya memiliki beberapa perbedaan. Kondisi itu sangat berpengaruh terhadap kemampuannya dalam melakukan aktivitas atau pekerjaannya, dari pagi, siang, sore dan bahkan malam hari (Nurhasan 2011, p.15).

Olahraga merupakan suatu kebutuhan bagi manusia, olahraga menurut Santosa (2012, p.37) adalah serangkaian gerak raga yang teratur dan terencana yang dilakukan orang dengan sadar untuk meningkatkan kemampuan fungsionalnya. Maka dari itu manusia sangat perlu untuk berolahraga guna menunjang kesehatan dan kebugaran jasmani. WHO sebagai organisasi badan kesehatan dunia (dalam Santosa, 2012, p.84) menjelaskan bahwa sehat adalah sejahtera jasmani, rohani dan sosial, bukan hanya bebas dari penyakit, cacat atau kelemahan yang berarti disebut sejahtera paripurna. Oleh karena itu peran pendidikan sekolah sangat penting untuk menselaraskan tujuan dalam menciptakan pola pembinaan dan pemeliharaan yang baik bagi siswa untuk mencapai tujuan sejahtera paripurna.

Melalui instansi sekolah, olahraga bisa diterapkan dalam kegiatan pembelajaran 
pendidikan jasmani dan kegiatan ekstrakurikuler, diharapkan mampu mewujudkan sehat sejahtera paripurna. Sesuai dengan sifat dan tujuannya olahraga olahraga dibagi menjadi; 1) Olahraga Prestasi yaitu olahraga sebagai tujuan, 2) olahraga rekreasi, kesehatan, pendidikan yaitu olahraga sebagai alat untuk mencapai tujuan (Santosa, 2012, p.37). Untuk menerapkannya peran pihak sekolah sangat penting bagi siswa dalam menerapkan sifat dan tujuan olahraga, baik melalui pengembangan diri baik secara fisiologis, mental, karakter siswa melalui olahraga.

Peran guru sebagai pelatih lebih spesifik lagi dalam memberikan edukasi dan pelatihan yang mampu memberikan dampak positif bagi kualitas fisik siswa. Pengetahuan dalam menciptakan program dan metode latihan merupakan kunci utama dalam upaya meningkatkan kualitas fisik siswa, hal itu karena berkaitan dengan perkembangan peforma siswa dan tujuan dari program latihan. Ada beberapa kriteria yang harus diamati pelatih, yaitu kemampuan teknik (Skills) yang dimiliki siswa dari proses bakat yang telah dilatih. Latihan yang dibutuhkan seorang atlet atau calon atlet (siswa) tidak hanya soal teknik dan taktik, akan tetapi yang terpenting adalah komponen fisik yang dicapai dengan latihan secara terus-menerus. Menurut Bompa (2009, p.61) faktor-faktor latihan yang perlu dipersiapkan latihan pada setiap cabang olahraga adalah: persiapan fisik, persiapan teknik, persiapan taktik, dan persiapan kejiwaan yaitu mental. Persiapan fisik, dan persiapan teknik merupakan dasar dalam membangun prestasi. Maka dari itu dasar utamanya yaitu latihan fisik yang akan dikembangkan dalam penelitian ini, tentunya sasaran dari latihan harus memenuhi kebutuhan komponen biomotorik. Menurut (Nala, 2011 p.2) menyebutkan terdapat 10 macam komponen biomotorik yang harus dimiliki seorang pemain atau atlet untuk mencapai kondisi puncak yaitu; 1) Daya Tahan (Endurance), 2) Kekuatan (Strength), 3) Kecepatan (Speed), 4) Kelincahan (Agility), 5) Daya Ledak (Power), 6) Kelenturan (Flexibility), 7) Ketepatan (Accuration), 8) Koordinasi (Coordination), 9) Jurnal IImiah Mandala Education
Keseimbangan (Balance), 10) Reaksi (Reaction). Sepuluh komponen biomotor tersebut tergantung kebutuhan komponen fisik yang dibutuhkan dalam bagian tubuhnya dan cabang olahraga apa yang ingin diminati.

Daya Ledak (Power) dan kelincahan merupakan komponen biomotor penting dalam meningkatkan performa otot tungkai. Menurut Soetanto et,al (2016, p.119) power didefinisikan sebagai produk dari kekuatan (force) dan kecepatan (velocity). Pelatihan kombinasi yang mengandung unsur kekuatan dan kecepatan bisa menghasilkan power. Latihan untuk peningkatan power dan agility (kelincahan) membutuhkan latihan variatif dan tersistem yaitu Plyometric. Latihan Plyometric adalah suatu metode untuk mengembangkan power (explosive power) suatu komponen penting dari sebagian besar prestasi atau kinerja olahraga (Racliffe dan Farentinos, 1985, p.3).

Latihan Plyometric juga bisa digunakan untuk meningkatkan kelincahan dan komponen biomotor lainnya. Seperti halnya penelitian sebelumnya Kumar Raj, (2013) "The Effect of 6 Week Plyometric Training Program On Agility of Collegiate Soccer Players" Pada kesimpulan dari penelitian ini adalah bahwa pelatihan Plyometric memberi pengaruh pada kelincahan pemain Sepak Bola. Begitu pula dengan penelitian Indrawati Rengga, (2016) yang berjudul "Pengaruh Latihan Lateral Cone Hops dan Cone Hops With Change of Direction Sprint Terhadap Power Otot Tungkai, Kelincahan, dan Kecepatan Reaksi". Pada penelitian tersebut terdapat kesimpulan bahwa latihan Lateral Cone Hops dan Cone Hops With Change of Direction Sprint berpengaruh signifikan dalam meningkatkan power otot Tungkai, kelincahan, kecepatan reaksi, meskipun tidak terdapat perbedaan yang signifikan antara keduanya dalam meningkatkan power otot Tungkai, kelincahan, dan kecepatan reaksi.

Plyometric mempunyai gerakan yang variatif dan membutuhkan sarana dan prasaran bermacam-macam untuk menunnjang latihannya, tentunya disesuaikan dengan kebutuhan cabang olahraga dan sasaran kelompok otot. Menurut Radcliffe dan 
Farentinos (1985, p.3) sebagian besar gerakan olahraga berasal dari tungkai dan pinggul misalnya, gerakan lari, lempar, loncat/lompat. Gerakan plyometric ada 3 kelompok besar yaitu diantaranya; 1) Tungkai dan Pinggul, 2) Togok, 3) Dada. (Radcliffe dan Farentinos).

Komponen biomotor power dan kelincahan (Agility) pada penelitian ini difokuskan pada bagian kelompok otot tungkai yang mana merupakan kelompok otot yang sangat dominan peranannya dalam kegiatan olahraga dan kegiatan sehari-hari. Latihan plyometric yang digunakan harus mengarah pada komponen biomotor power dan kelincahan, untuk itu rencana penelitian ini mengambil jenis latihan Plyometric Cone Hop With 180-Degree Turn, Lateral Jump Over Barrier, Lateral Cone Hops. Pada tiga bentuk latihan yang digunakan terdapat gerakan melompat yang dominan dan variasi perpindahan gerakan putaran180 derajat, perpindahan gerakan lompatan ke samping (lateral) secara cepat, perpindahan gerakan lompatan kanan dan kekiri melintasi cone sehingga bisa diasumsikan latihan ini bisa di rekomendasikan untuk diteliti sejauh mana hasil dari tiga bentuk latihan tersebut yang memiliki variasi gerakan yang berbeda.

$\begin{array}{rrr}\text { SMA Negeri } 1 & \text { Batuan merupakan } \\ \text { sekolah memiliki } & \text { banyak program }\end{array}$ keolahragaan, baik di tingkat kegiatan antar siswa (internal), maupun program ekstrakurikuler. Namun permasalahan dalam kegiatan olahraga kondisi fisik terutama dari segi komponen bimotor. Radcliffe dan Farentinos (1985, p.3) berpendapat, sebagian besar gerakan olahraga berasal dari tungkai dan pinggul misalnya, gerakan lari, lempar, loncat/lompat. Hal ini tentunya perlu latihan yang sasarannya adalah kelompok otot tungkai, dan komponen biomotor yang paling dominan peranannya di otot tungkai yaitu Power dan kelincahan.

Dalam rangka mendukung dan meningkatkan kualitas fisik Kelompok otot tungkai yang nantinya akan digunakan pada kegiatan olahraga di SMA Negeri 1 Batuan, perlu adanya edukasi mengenai model dan metode latihan apa saja yang bisa diterapkan dalam kegiatan sehari hari, untuk itu rencana penelitian ini ditujukan untuk mengedukasi Jurnal Ilmiah Mandala Education dan memberikan pemahaman kepada guru sebagai pelatih untuk meningkatkan prestasi dan kebugaran siswa terutama bagi pemula melalui tiga latihan plyometric ini.

Peneilitian ini dirancang untuk upaya pengembangan dari research (penelitian) terdahulu, yaitu diantaranya Kumar Raj (2013) "The Effect of 6 Week Plyometric Training Program On Agility of Collegiate Soccer Players 'Pada kesimpulan dari penelitian ini adalah bahwa pelatihan Plyometric memberi pengaruh pada kelincahan pemain Sepak Bola. Indrawati Rengga (2016) "Pengaruh Latihan Lateral Cone Hops dan Cone Hops With Change of Direction Sprint Terhadap Power Otot Tungkai, Kelincahan, dan Kecepatan Reaksi". Pada kesimpulan penelitian ini dapat disimpulkan bahwa latihan Lateral Cone Hops dan Cone Hops With Change of Direction Sprint berpengaruh signifikan dalam meningkatkan power otot Tungkai, kelincahan, kecepatan reaksi, dan tidak terdapat perbedaanyang signifikan antara keduanya dalam meningkatkan power otot Tungkai, kelincahan, dan kecepatan reaksi. Satar Hayyun (2016) "Pengaruh Latihan Front Cone Hops dan Lateral Cone Hops terhadap Peningkatan Daya Ledak Otot Tungkai dan Kelincahan". Pada kesimpulan penelitian ini bahwa terdapat daya ledak otot tungkai dan kelincahan pada kelompok 1 dan kelompok 2 Setelah diberikan latihan. Selain itu, terdapat perbedaan pengaruh antara ketiga kelompok dilihat dari peningkatan daya ledak otot tungkai dan kelincahan. Taheri et al (2014) "The effect of 8 weeks of plyometric and resistance training on agility, speed and explosive power in soccer players" Penelitian ini memiliki kesimpulan, dapat disimpulkan bahwa latihan latihan plyometric dan resistance efektif meningkatkan ketangkasan dan daya ledak dan mempercepat waktu sprint pada pemain sepak bola. Latihan plyometric lebih banyak efek yang signifikan pada variabel penelitian dibandingkan dengan latihan ketahanan.

Adapun Perbedaan dan persamaan penelitian terdahulu dengan penelitian yang saat ini akan dilakukan adalah terletak pada kriteria usia, sampel dan populasi siswa pemula (non atlet/ tidak mengikuti 
ekstrakurikuler olahraga), serta lokasi/tempat penelitian serta model latihan yang di terapkan. Persamaannya terletak pada variabel terikat yakni Power otot tungkai dan kelincahan sebagai tujuan peningkatan biomotor. Keunggulan penelitian ini yaitu memakai tiga bentuk latihan yang berbeda, sedangkan penelitihan terdahulu hanya menggunakan dua bentuk latihan Plyometric saja.

Maka dari itu peneliti melakukan penelitian berjudul "Pengaruh latihan Plyometric Cone Hop With 180-Degree Turn, Lateral Jump Over Barrier, Lateral Cone Hops terhadap peningkatan Power otot tungkai dan kelincahan" untuk mengkaji lagi dan mengembangkan penelitian sebelumnya.

\section{METODE PENELITIAN}

Penelitian ini menggunakan pendekatan kuantitatif dengan jenis penelitian eksperimen semu (quasi experiment). Desain yang digunakan dalam penelitian ini yaitu Matching-Only Design dan dilakukan dua kali pengambilan posttest untuk mengetahui hasil perkembangan setelah diberikan perlakuan (treatment). Data pretest dan posttest yang ke dua adalah hasil pemelitian yang menjadi data acuan untuk uji hipotesis setelah diberikan treatment selama 8 minggu. Menurut Maksum (2012, p.100) Matching Only Design yaitu memasukkan subjek satu dengan yang lainnya berdasarkan variabel tertentu Matching-Only Design dapat digambarkan sebagai berikut.

\begin{tabular}{l|lllll|}
\hline$M$ & $\mathrm{~T}_{1}$ & $\mathrm{X}_{1}$ & $\mathrm{~T}_{2}$ & $\mathrm{X}_{2}$ & $\mathrm{~T}_{3}$ \\
\hline $\mathrm{M}$ & $\mathrm{T}_{4}$ & $\mathrm{X}_{3}$ & $\mathrm{~T}_{5}$ & $\mathrm{X}_{4}$ & $\mathrm{~T}_{6}$ \\
\hline $\mathrm{M}$ & $\mathrm{T}_{7}$ & $\mathrm{X}_{5}$ & $\mathrm{~T}_{8}$ & $\mathrm{X}_{6}$ & $\mathrm{~T}_{9}$ \\
\hline $\mathrm{M}$ & $\mathrm{T}_{10}$ & - & $\mathrm{T}_{11}$ & - & $\mathrm{T}_{12}$ \\
\hline
\end{tabular}

\section{Gambar 1. Desain Penelitian}

\section{Keterangan:}

\section{M : Matching}

$\mathrm{T}_{1} \quad$ : Pretest kelompok Cone Hop With 180-degree Turn

$\mathrm{T}_{4} \quad$ : Pretest kelompok Lateral Jump Over Barrier

$\mathrm{T}_{7} \quad$ : Pretest kelompok Lateral Cone Hops

$\mathrm{T}_{10}:$ Pretest kelompok kontrol

$\mathrm{X}_{1}, \mathrm{X}_{2}$ : Treatment kelompok eksperimen Cone Hop With 180degree Turn

$\mathrm{X}_{3}, \mathrm{X}_{4}$ : Treatment kelompok eksperimen Lateral Jump Over Barrier

$\mathrm{X}_{5}, \mathrm{X}_{6}$ : Treatment kelompok eksperimen Lateral Cone Hops

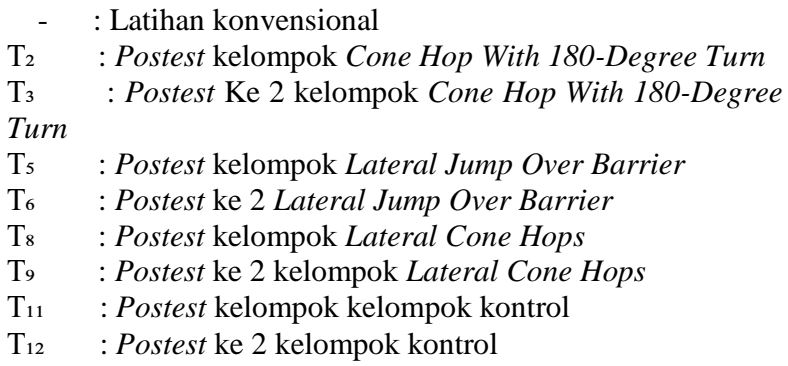

Desain Penelitian diambil dari sampel siswa kelas XI Putra yang berusia 16-17 tahun yang memenuhi kriteria lainnya berjumlah 40 orang, kemudian dibagi menjadi 4 kelompok. Masing-masing kelompok dilakukan pretest yaitu kelompok eksperimen sebagai data $\left(\mathrm{T}_{1}\right)$, $\left(\mathrm{T}_{7}\right)$ dan $\left(\mathrm{T}_{8}\right)$ serta kelompok kontrol sebagai data $\left(\mathrm{T}_{10}\right)$. Pada proses pengelompokan tidak menggunakan random namun penempatannya dilakukan dengan skema Ordinal Pairing agar kelompok merata. Kelompok eksperimen diberi perlakuan $\left(\mathrm{X}_{1}\right),\left(\mathrm{X}_{2}\right)$ yaitu latihan $\left(\mathrm{X}_{3}\right)$, $\left(\mathrm{X}_{4}\right)$, Cone Hop With 180-Degree Turn, ,( $\left.\mathrm{X}_{5}\right)$, $\left(\mathrm{X}_{6}\right)$ yaitu latihan Lateral Jump Over Barrier, dan yaitu latihan Lateral Cone Hops. Kelompok kontrol diberi program latihan konvensional, yaitu latihan yang diberikan sesuai dengan program latihan biasa tanpa ada tambahan latihan Cone Hop With 180-Degree Turn, Lateral Jump Over Barrier, Lateral Cone Hops. Setelah empat minggu latihan, selanjutnya dilakukan Posttest pertama kepada keempat kelompok $\left(\mathrm{T}_{2}\right),\left(\mathrm{T}_{5}\right),\left(\mathrm{T}_{8}\right)$ dan $\left(\mathrm{T}_{11}\right)$. Setelah empat minggu latihan, selanjutnya dilakukan Posttest kedua kepada keempat kelompok $\left(\mathrm{T}_{3}\right),\left(\mathrm{T}_{6}\right),\left(\mathrm{T}_{9}\right)$ dan $\left(\mathrm{T}_{12}\right)$.

Populasi penelitian yaitu keseluruhan dari siswa kelas XI SMA Negeri 1 Batuan yaitu 148 terdiri dari 98 siswa lakilaki dan 50 siswa perempuan. Sampel penelitian berjumlah 40 orang. Hal ini sesuai dengan jumlah minimal peserta yang dijadikan eksperimen. Adapun pembagian kelompok sampel pada penelitian ini yaitu dengan melewati proses tahapan melaksanakan pretest dari variabel terikat untuk diketahui ranking tinggi dan rendahnya dari sampel yang berjumlah 40 orang. Setelah mengetahui hasil tes, subyek dibagi kedalam beberapa kelompok dengan teknik Ordinal Pairing yaitu polanya sebagai berikut. 
Tabel 1. Skema Ordinal Pairing

\begin{tabular}{lllllllllll}
\hline $\mathrm{K} 1$ & 1 & 8 & 9 & 16 & 17 & 24 & 25 & 32 & 33 & 40 \\
\hline $\mathrm{K} 2$ & 2 & 7 & 10 & 15 & 18 & 23 & 26 & 31 & 34 & 39 \\
\hline $\mathrm{K} 3$ & 3 & 6 & 11 & 14 & 19 & 22 & 27 & 30 & 35 & 38 \\
\hline $\mathrm{K} 4$ & 4 & 5 & 12 & 13 & 20 & 21 & 28 & 29 & 36 & 37 \\
\hline
\end{tabular}

Keterangan:

$\mathrm{K} 1$ = Kelompok 1 (Kelompok Cone Hop With 180Degree Turn)

$\mathrm{K} 2$ = Kelompok 2 (Kelompok Lateral Jump Over Barrier)

K3 = Kelompok 3 (Kelompok Lateral Cone Hops)

K4 = Kelompok 4 (Kelompk kontrol)

Jenis instrumen yang digunakan untuk mengukur power otot tungkai yaitu dengan menggunakan tes Standing Broad Jump. Sedangkan untuk instrumen yang digunakan untuk mengukur kelincahan yaitu dengan Agilityt-test. Setelah data terkumpul hasil tesnya lalu dirangking untuk mengetahui yang unggul, setelah itu subyek dibagi kedalam beberapa kelompok dengan pola Ordinal Pairing. Sehubungan dengan satuan Power dan Kelincahan berbeda maka dilakukan proses T-score untuk menyetarakannya. Setelah itu hasil yang tercatat akan dihitung berdasarkan kelompok yang menggunakan latihan yang telah ditentukan, maka dilakukan analisis data menggunakan analisis statistik deskriptif dengan aplikasi SPSS 22.0. Uji normalitas,uji homogenitas, dan uji hipotesis menggunakan multivariant analysis of varian (Manova) dikondukasikan dalam penelitian ini masing-masing pada tarap signifikansi 0.05.

\section{HASIL DAN PEMBAHASAN}

Hasil analisis deskriptif digunakan untuk memberikan gambaan hasil penelitian yang telah dilakukan. Adapun isi dari pemaparan deskriptif adalah membahas tentang data nilai jumlah data, nilai maksimal, nilai minimal, nilai rata rata dan nilai standar deviasi. Data hasil yang didapat melalui hasil penelitian yang akan dideskripsikan yaitu dari hasil data awal atau Pretest dan hasil data setelah penelitian atau Posttest. Analisis data deskriptif yang akan dilakukan menggunakan progam aplikasi SPSS 22. Penelitian ini menggunakan tiga variabel sebagai aspek penelitian, yaitu Kelincahan dan power otot tungkai. Untuk power otot tungkai pengukuran Standing broad jump dilakukan dengan menggunakan tes, dan untuk mengukur kelincahan menggunakan tes $A F L$. Selain itu Jurnal Ilmiah Mandala Education dalam penelitian ini menggunakan tiga kelompok, yaitu kelompok Cone Hop with 180 degree turn sebagai kelompok 1, Lateral jump over barrier sebagai kelompok 2 dan kelompok Lateral Cone Hops sebagai kelompok 3. Pada Tabel 2 berikut dapat didiskripsikan beberapa hasil pretest dan posttest.

Tabel 2. Data hasil Pretest Posttest 1, dan Posttest 2 Cone Hop With 180 Degree Turn

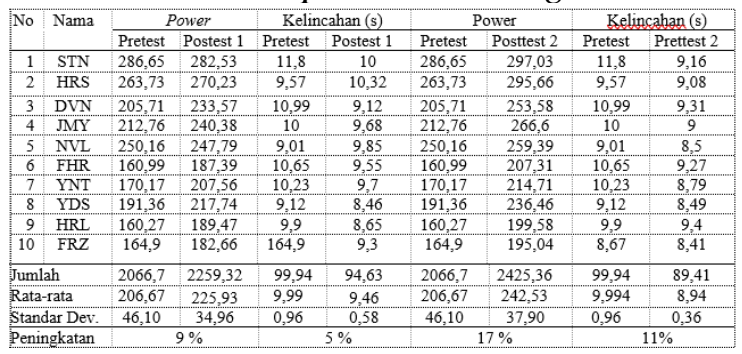

Hasil pretest dan posttest kelompok 1

(Cone Hop Witth 180 Degree turn) memiliki jumlah dan rata-rata yang berbeda, Pada pretest ke 1 power 206,67 dan posttest 225,93. Pada pretest kelincahan 9,99 dan posttest 9,46. Jadi terjadi peningkatan sebanyak $9 \%$ dari variabel Power dan kelincahan 5\% peningkatan. Kelompok 1 (Cone Hop Witth 180 Degree turn) Pretetest power 206,67dan Posttest ke 2 yaitu 242,53 mengalami peningkatan $17 \%$. Sedangkan hasil rata-rata kelincahan pretest 9,99 dan posttest 8,94 terjadi peningkatan sebesar $11 \%$.
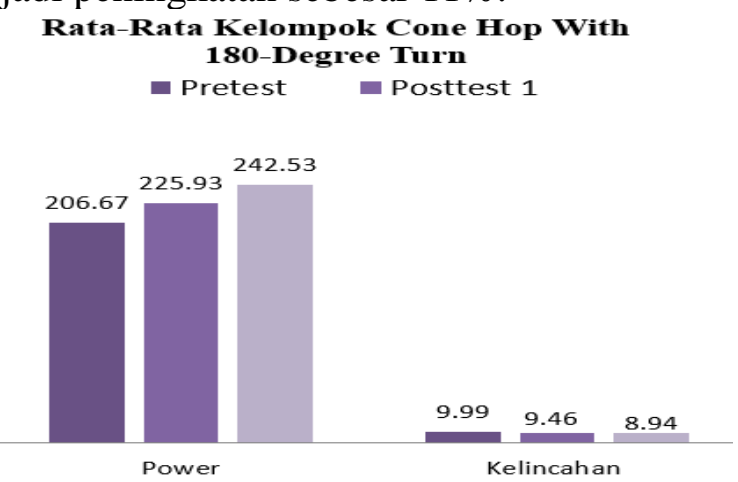

Gambar 2. Grafik rata-rata pretest, posttest 1 dan posttest 2 kelompok Cone Hop With 180 Degree Turn

Pada gambar 2 dijelasan bahwa kelompok 1 (Cone Hop Witth 180 Degree turn) Pretetest, Posttest 1 dan Posttest 2 mengalami peningkatan setelah dilakukannya pemberian latihan plyometric Cone Hop With 180-Degree Turn. Grafik di gambar 2 menunjukkan perubahan nilai rata-rata semua kelompok 
perlakuan mengalami peningkatan. Peningkatan paling signifikan terjadi setelah dilakkannya posttest yang ke 2 yakni dengan $17 \%$ pada variabel power dan $11 \%$ pada variabel kelincahan. Deskripsi data kelompok lateral jump over barrier dijelaskan pada Tabel 3.

Tabel 3. Data Hasil Pretest dan Posttest 1dan Posttest 2 kelompok Lateral Jump Over

Barrier

\begin{tabular}{|c|c|c|c|c|c|c|c|c|c|}
\hline & \multirow[b]{2}{*}{ Nama } & \multicolumn{2}{|c|}{ Power (Watt) } & \multicolumn{2}{|c|}{ Kelincahan (s) } & \multicolumn{2}{|c|}{ Power (Watt) } & \multicolumn{2}{|c|}{ Kelincahan (s) } \\
\hline & & Pretest & Posttest 1 & Pretest & Posttest 1 & Pretest & Posttest 2 & Pretest & Posttest 2 \\
\hline 1 & TFK & 269,55 & 288.24 & 11,6 & 11,10 & 269,55 & 276,18 & 11,6 & 11.08 \\
\hline 2 & DMS & 161,48 & 163,66 & 12,22 & 11,06 & 161,48 & 182,55 & 12,22 & 10,89 \\
\hline 3 & DTO & 283,69 & 257,07 & 9,01 & 8,98 & 283,69 & 265,36 & 9,01 & 8.85 \\
\hline 4 & SFL & 176,42 & 182,26 & 11,09 & 9,9 & 176,42 & 177,18 & 11,09 & 9,2 \\
\hline 5 & HVL & 149,45 & 146,67 & 11,5 & 10 & 149,45 & 155,47 & 11,5 & 9,76 \\
\hline 6 & OKY & 201,23 & 226,94 & 9,64 & 9,66 & 201,23 & 210,59 & 9,64 & 9,88 \\
\hline 7 & ALI & 176,96 & 189,25 & 10 & 9,88 & 176,96 & 201,51 & 10 & 8,82 \\
\hline 8 & ARF & 219,78 & 238,21 & 8,42 & 8,45 & 219,78 & 237,18 & 8,42 & 8,48 \\
\hline 9 & IBN & 198,49 & 201,00 & 8,93 & 8,95 & 198,49 & 202,31 & 8,93 & 9,5 \\
\hline 10 & IRN & 151,2 & 163,98 & 9,53 & 9,5 & 151,2 & 180,96 & 9,53 & 8.9 \\
\hline \multicolumn{2}{|c|}{ Jumlah } & 1988,25 & 2057,3 & 101,94 & 97,48 & 1988,25 & 2089,29 & 101,9 & 95,36 \\
\hline \multirow{2}{*}{\multicolumn{2}{|c|}{$\begin{array}{l}\text { Rata-Rata } \\
\text { Standar Dev. }\end{array}$}} & 198,82 & & 10,19 & & & & 10,19 & \\
\hline & & & 45 & 1,31 & 0,8 & 46,82 & 39,37 & 1,31 & 0,88 \\
\hline \multicolumn{2}{|c|}{ Peningkatan } & \multicolumn{2}{|c|}{$3 \%$} & \multicolumn{2}{|c|}{$4 \%$} & & \\
\hline
\end{tabular}

Pada Tabel 3 dapat dijelaskan hasil pretest dan posttest kelompok 2 (Lateral Jump Over Barrier) hasil jumlah dan rata-rata yang meningkat, Pada pretest power 198,82 dan posttest 205,73. Pada pretest kelincahan nilai rata-ratanya 10,19 dan posttest ke 1 nilai rataratanya 9,74. Jadi terjadi peningkatan sebanyak 3\% dari Variabel Power dan kelincahan $4 \%$ peningkatan. Maka dapat disimpulkan bahwa dengan pemberian latihan Lateral Jump Over Barrier hasilnya terdapat peningkatan nilai rata-rata setelah pemberian pelakuan. Pada Tabel 3 juga dapat dijelaskan nilah hasil pretest dan posttest 2 kelompok 2 (Lateral Jump Over Barrier) memiliki jumlah dan rata-rata yang berbeda. Pada pretest power 198,83 dan posttest 208,92 Pada pretest kelincahan 10,19 dan posttest 9,53. Jadi terjadi peningkatan sebanyak 5\% dari Variabel Power dan kelincahan $6 \%$ peningkatan. Maka dapat disimpulkan bahwa dengan pemberian latihan Lateral Jump Over Barrier hasilnya terdapat peningkatan nilai rata-rata setelah pemberian pelakuan.

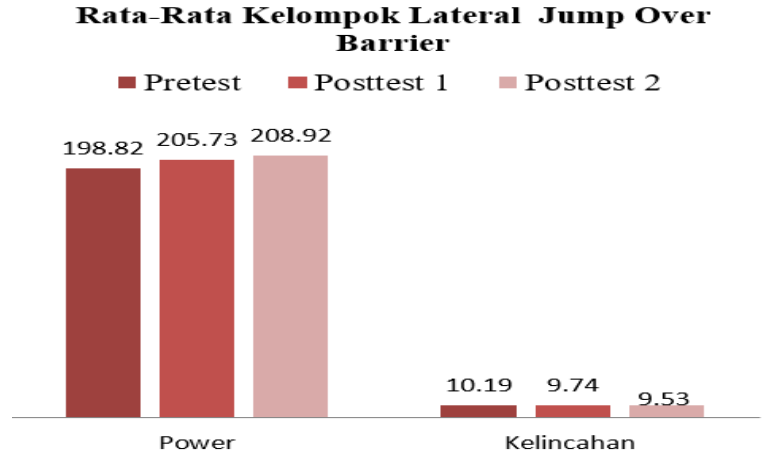

Gambar 3. Grafik rata-rata pretest, posttest 1 dan posttest 2 kelompok Lateral Jump Over Barrier

Tes Power Otot Tungkai menggunakan tes Standing Broad Jump sedangkan kelincahan pengukurannya menggunakan parameter tes $A F L$ dan menggunakan satuan detik. Pada Grafik di gambar 3 menunjukkan perubahan nilai rata-rata semua kelompok perlakuan mengalami peningkatan. Peningkatan paling signifikan terjadi setelah dilakkannya posttest yang ke 2 yakni dengan $5 \%$ pada variabel power dan $6 \%$ pada variabel kelincahan. Deskripsi data kelompok lateral cone hops disajikan pada Tabel 4.

Tabel 4. Data Hasil Pretest, Posttest 1 dan

Posttest 2 kelompok Lateral Cone Hops

\begin{tabular}{|c|c|c|c|c|c|c|c|c|c|}
\hline No & Nama & \multicolumn{2}{|c|}{$\begin{array}{l}\text { Power } \\
\end{array}$} & \multicolumn{2}{|c|}{ Kelincahan (s) } & \multicolumn{2}{|c|}{ Power } & \multicolumn{2}{|c|}{$\begin{array}{l}\text { Kelincahan (s) } \\
\text { Pretest } \\
\text { Postestes }\end{array}$} \\
\hline$\frac{1}{1}$ & $\mathrm{ADT}$ & $\frac{\text { Pretelst }}{228.42}$ & $\begin{array}{l}\text { Postitest } 1 \\
265.92\end{array}$ & $\begin{array}{l}\frac{P \text { retestest }}{12.34} \\
\end{array}$ & $\begin{array}{l}\text { Postlest } 1 \\
10.66\end{array}$ & $\begin{array}{l}\text { Pretest } \\
228.42\end{array}$ & Postlest 2 & $\begin{array}{l}\text { Pretest } \\
1.34\end{array}$ & $\begin{aligned} \text { Postlest } 2 \\
9.96\end{aligned}$ \\
\hline 2 & JND & 197,78 & 203,52 & 11,36 & 10,4 & 197,78 & 212,59 & 11,36 & 9,89 \\
\hline 3 & $\mathrm{YGA}$ & 275,22 & 244,83 & 8,84 & 9 & 275,22 & 250,77 & 8,84 & 8,82 \\
\hline 4 & ALF & 232,56 & 239,38 & 8.95 & 9,29 & 232,56 & 253,72 & 8,95 & 8.64 \\
\hline 5 & ABR & 239,56 & 257,65 & 9,11 & 9 & 239.56 & 267,2 & 9,11 & 8.66 \\
\hline 6 & FQR & 170,24 & 166,13 & 10,52 & 9,8 & 170,24 & 188,81 & 10,52 & 9 \\
\hline 7 & USM & 169,64 & 182,50 & 10,03 & 9,67 & 169,64 & 183.85 & 10,03 & 9,07 \\
\hline 8 & MRZ & 189,25 & 205,36 & 9,25 & 9,01 & 189,25 & 221,47 & 9,25 & 8,74 \\
\hline 9 & RFQ & 162,67 & 185,78 & 9,55 & 9,42 & 162,67 & 195,2 & 9,55 & 9,56 \\
\hline 10 & BHR & 156.8 & 186,29 & 9,54 & 9,22 & 156,8 & 184,16 & 9,54 & \\
\hline Jumlat & & 2022,14 & 2137,42 & 99,49 & 95,47 & 2022,14 & 2229,41 & 99,49 & 91,34 \\
\hline suod t & & 202,21 & 213,74 & 9,94 & 9,54 & 202,21 & 222.94 & 9,94 & 9,13 \\
\hline & & 39,76 & 35,32 & 1,14 & 0,58 & 39,76 & 35,16 & 1,14 & \\
\hline
\end{tabular}

Hasil tabel 4 dapat dijelaskan hasil pretest dan posttest kelompok 3 (Lateral Cone Hops) memiliki jumlah dan rata-rata yang berbeda dan terjadi peningkatan. Pada pretest power 202,21 dan posttest 213,74 sedangkan pretest kelincahan 9,94 dan posttest 9,54. Jadi terjadi peningkatan sebanyak $6 \%$ dari Variabel Power dan kelincahan $4 \%$ peningkatan. Maka dapat disimpulkan bahwa dengan pemberian latihan Lateral Cone Hop hasilnya terdapat peningkatan nilai rata-rata setelah pemberian pelakuan.

Pada Tabel 4 juga dijelaskan hasil pretest dan posttest 2 kelompok 3 (Lateral Cone Hops) memiliki jumlah dan rata-rata yang berbeda. Pada pretest power 202,21 dan 
posttest 222,94 sedangkan pretest kelincahan 9,94 dan posttest 9,13, terjadi peningkatan sebanyak $10 \%$ dari Variabel Power dan kelincahan $8 \%$ peningkatan. Maka dapat disimpulkan bahwa dengan pemberian latihan Lateral Jump Cone Hop hasilnya terdapat peningkatan nilai rata-rata setelah pemberian pelakuan.

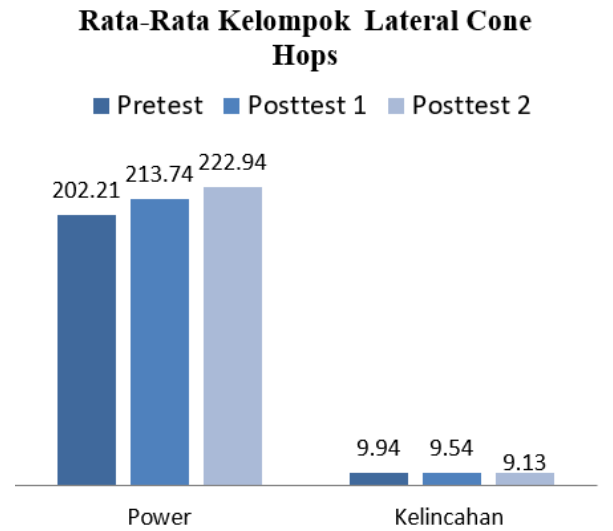

Gambar 4. Grafik rata-rata pretest dan posttest 1, dan Posttest 2 Lateral Cone Hops.

Pada gambar 4 dijelasan bahwa kelompok 3 (Lateral Cone Hops) Pretetest dan Posttest mengalami peningkatan $6 \%$. Sedangkan hasil rata-rata kelincahan pretest dan posttest terjadi peningkatan sebesar $4 \%$. Sedangkan Pretetest dan Posttest ke 2 sebesar mengalami peningkatan $10 \%$. Sedangkan hasil rata-rata kelincahan pretest dan posttest terjadi peningkatan sebesar 8\%. Deskripsi data kelompok kontrol disajikan pada Tabel 5.

Tabel 5. Data Hasil Pretest, Posttest 1, dan posttest 2 kelompok Kontrol

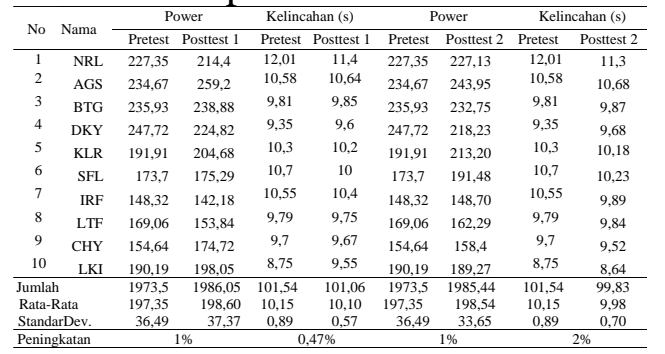

Pada Tabel 5 dijelaskan bahwa hasil pretest kontrol pada variabel power 197,35 sedangkan posttest variabel power hasil rataratanya 198,60 dengan peningkatan $1 \%$, sedangkan pada variabel kelincahan pretest kelompok kontrol rata-ratanya 10,15, sedangkan hasil posttest nilai rata-ratanya sebesar 10,10 dengan peningkatan 0,47\%. Pada hasil pretest dan posttest 2 kelompok 4 (Kontrol) memiliki jumlah dan nilai rata-rata yang berbeda. Pada pretest power 197,35 dan posttest 198,54 sedangkan pretest kelincahan 10,15 dan posttest 9,98 terjadi peningkatan dari Variabel Power yaitu 1\%, sedangkan kelincahan $2 \%$ peningkatan.

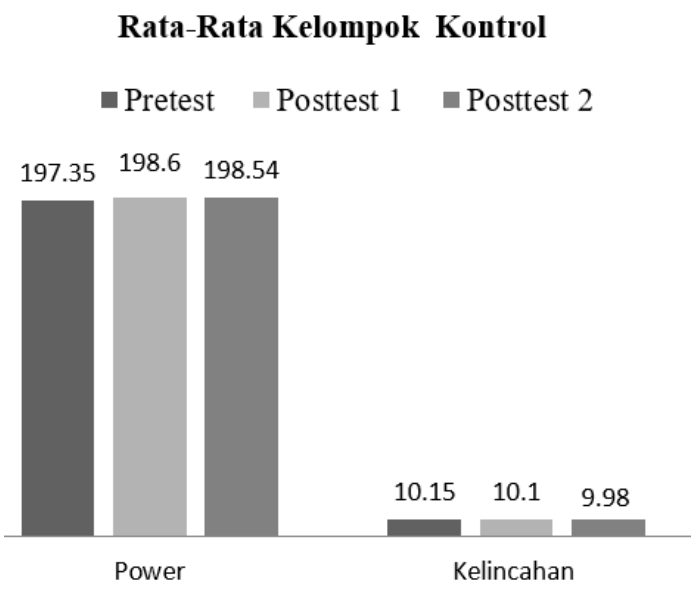

Gambar 5. Grafik rata-rata pretest, posttest 1 dan posttest 2 Kontrol.

Pada gambar 5 dijelasan bahwa kelompok 4 (kontrol) tidak terjadi peningkatan yang signifikan baik pretest, posttest, dan posttest ke 2 . Hasil pretest dan posttest 1 kontrol pada variabel power $1 \%$, sedangkan pada variabel kelincahan pretest dan posttest 1peningkatannya $0,47 \%$. Pada hasil pretest dan posttest 2 kelompok 4 (Kontrol) pretest power,dan posttest sebesar $1 \%$ peningkatan sedangkan kelincahan yaitu $2 \%$ peningkatan.

Uji prasyarat dilakukan sebelum uji beda paired sample t test. Uji prasyarat terdirir dari uji normalitas dan uji homogenitas. Uji normalitas digunakan untuk mengetahui data yang didapatkan berdistribusi normal atau tidak. Sedangkan uji homogenitas adalah untuk mengetahui data memiliki varian yang sama atau homogen. Uji normalitas digunakan sebagai acuan untuk menuju uji selanjutnya. berikut ini adalah cara pengujian uji normalitas. Kriteria pengujian data berdistribusi normal jika tingkat signifikan (p) $>\alpha=0,05$ maka data berdistribusi normal dan jika tingkat signifikan $(\mathrm{p})<\alpha=0,05$ maka data tidak berdistribusi normal. 
Tabel 6. Uji Normalitas Data

\begin{tabular}{llccccccc}
\hline \multirow{2}{*}{ Variabel } & \multirow{2}{*}{ Test } & Kel. 1 & Kel. 2 & Kel. 3 & Kontrol & \multirow{2}{*}{ Ket. } & \multirow{2}{*}{ Status } \\
\cline { 3 - 7 } & & Sig. & Sig. & Sig. & Sig. & & \\
\hline \multirow{2}{*}{ Power Otot Tungkai } & Pretest & 0,163 & 0,161 & 0,330 & 0,287 & P>0,05 & Normal \\
& Posttest 2 & 0,348 & 0,429 & 0,120 & 0,456 & P>0,05 & Normal \\
\hline \multirow{2}{*}{ Kelincahan } & Pretest & 0,911 & 0,442 & 0,096 & 0,710 & P>0,05 & Normal \\
& Posttest 2 & 0,218 & 0,221 & 0,061 & 0,745 & P>0,05 & Normal \\
\hline
\end{tabular}

Berdasarkan pada Tabel 6 di atas diketahui bahwa nilai data Pretest dan Posttestt dari kelompok 1, kelompok 2 dan kelompok 3 memiliki data signifikan $(\mathrm{p})>\alpha=$ 0,05, maka dapat disimpulkan bahwa data terssebut berdistribusi normal. Sedangkan nilai Posttest ke 2 dari kelompok 1, kelompok 2 dan kelompok 3 memiliki data signifikan $(\mathrm{p})>\alpha=$ 0,05, maka dapat disimpulkan bahwa data tersebut berdistribusi normal.

Uji homogenitas ini digunakan untuk memperlihatkan bahwa dua atau lebih kelompok data sampel berasal dari populasi yang memiliki varian yang sama. Adapun kriteria uji homogenitas data jika tingkat signifikan $(p)>\alpha=0,05$ maka varians homogen, jika tingkat signifikan $(p)<\alpha=0,05$ maka varians tidak homogen.

Tabel 7. Uji Homogenitas Data

\begin{tabular}{lcccc}
\hline & Levene Statistic & df1 & df2 & Sig. \\
\hline Pretest Power & 0,147 & 3 & 36 & 0,931 \\
Pretest Kelincahan & 0,561 & 3 & 36 & 0,644 \\
Postest ke 2 Power & 0,064 & 3 & 36 & 0,979 \\
Postest ke 2 Kelincahan & 1,866 & 3 & 36 & 0,153 \\
\hline
\end{tabular}

Berdasarkan hasil pada tabel 7 diatas diketahui bahwa nilai data pretest, posttest dan posttest ke 2 memiliki data signifikan (p) $>\alpha=$ 0,05, maka dapat disimpulkan bahwa data memiliki varian yang sama atau Homogen. Selanjutnya dilakukan uji paired sampel t test untuk mengetahui apakah terdapat pengaruh dari treatment atau perlakuan dari pretest dan posttest termasuk kelompok kontrol yang tidak diberikan perlakuan. Setelah uji prasyarat seperti uji Normalitas dan Homogenitas dilakukan, jika hasilnya normal dan homogenya maka bisa dilanjutkan dengan uji parametrik Uji Paired Test.

Tabel 8. Hasil Paired Sample T Test

Kelompok Cone Hops With 180-degree turn

\begin{tabular}{llc}
\hline & & Sig. (2-tailed) \\
\hline \multirow{2}{*}{ Cone Hop with-180 degree turn } & Power & 0,000 \\
& Kelincahan & 0,001 \\
\hline
\end{tabular}

Hasil uji-t paired t-test pada latihan Cone Hops 180 degree turn dengan nilai Sig. (2-tailed) 0.000 pada variabel power dan nilai
Sig. (2-tailed) 0.001 pada variabel kelincahan, maka disimpulkan bahwa $\mathrm{HO}$ ditolak dan $\mathrm{Ha}$ diterima karena nilai Sig. $0.000<$ nilai $\alpha=0,05$ dan $0.001<$ nilai $\alpha=0,05$. Dengan kesimpulan terdapat pengaruh yang signifikan dari pemberian latihan Cone Hop with 180-degree turn terhadap power otot tungkai dan kelincahan.

Tabel 9. Hasil Paired Sample T Test

Kelompok Lateral Jump Over Barier

\begin{tabular}{llc}
\hline & & Sig. (2-tailed) \\
\hline \multirow{2}{*}{ Lateral Jump Barier } & Power & 0,047 \\
& Kelincahan & 0,037 \\
\hline
\end{tabular}

Hasil dari perhitungan uji-t paired $t$ test pada pemberian latihan Lateral Jump over Barier dengan melihat nilai Sig. (2-tailed) 0.047 pada variabel power dan nilai Sig. (2tailed) 0.037 pada variabel kelincahan, maka dapat disimpulkan bahwa $\mathrm{HO}$ ditolak dan $\mathrm{Ha}$ diterima karena nilai Sig. $0.0047<$ nilai $\alpha=$ 0,05 dan $0.037<$ nilai $\alpha=0,05$. Jadi dapat disimpulkan terdapat pengaruh yang signifikan dari pemberian latihan Lateral Jump Over Barrier terhadap power otot tungkai dan kelincahan.

Tabel 10. Hasil Paired Sample T Test Kelompok Lateral Cone Hops

\begin{tabular}{llc}
\hline & & Sig. (2-tailed) \\
\hline \multirow{2}{*}{ Lateral Cone Hops } & Power & 0,006 \\
& Kelincahan & 0,008 \\
\hline
\end{tabular}

Hasil dari perhitungan uji-t paired $t$ test pada kelompok Lateral Cone Hops pada posttest ke 2 dengan melihat nilai Sig. (2tailed) 0.006 pada variabel power dan nilai Sig. (2-tailed) 0.008 pada variabel kelincahan, maka dapat disimpulkan bahwa $\mathrm{H}_{0}$ ditolak dan Ha diterima karena nilai Sig. $0.006<$ nilai $\alpha=$ 0,05 dan $0.008<$ nilai $\alpha=0,05$. Jadi terdapat pengaruh yang signifikan dari latihan Lateral Cone Hops terhadap peningkatan kelincahan dan power otot tungkai.

Tabel 11. Hasil Paired Sample T Test Kelompok Kontrol

\begin{tabular}{llc}
\hline & & Sig. (2-tailed) \\
\hline \multirow{2}{*}{ Kontrol } & Power & 0,794 \\
& Kelincahan & 0,148 \\
\hline
\end{tabular}

Hasil dari perhitungan uji-t paired $t$ test pada kelompok Kontrol dengan melihat nilai Sig. (2-tailed) 0.794 pada variabel power 
dan nilai Sig. (2-tailed) 0.148 pada variabel kelincahan, maka dapat disimpulkan bahwa H0 diterima dan Ha ditolak karena nilai Sig. $0.794>$ nilai $\alpha=0,05$ dan $0.148>$ nilai $\alpha=$ 0,05 . Dengan kata lain tidak terdapat pengaruh yang signifikan dari kelompok kontrol terhadap peningkatan kelincahan dan power otot tungkai.

Uji Multivariate analisis of variance (Manova) digunakan untuk melihat perbedaan variabel yang muncul dari empat kelompok maka harus diuji secara bersamaan. Dasar pengambilan keputusan dalan analisis Manova, yaitu a) peluang terjadinya kesalahan $\alpha=0.05$, b) Ho ditolak atau Ha diterima, jika nilai probabilitas signifikansi $<0.05$ yang artinya nilai sig kurang dari 0,05 maka terdapat perbedaan yang signifikan antara ketiga jenis latihan dan kelompok kontrol terhadap Power dan kelincahan, dan c) Ho diterima atau $\mathrm{Ha}$ ditolak, jika nilai probabilitas signifikansi > 0.05 maka tidak terdapat perbedaan yang signifikan antara ketiga jenis latihan terhadap Power dan kelincahan.

Tabel 12. Hasil Perhitungan Manova

\begin{tabular}{llrrrrr}
\hline & Effect & \multicolumn{1}{c}{ Value } & \multicolumn{1}{c}{ F } & Hyp. df & Error df & Sig. \\
\hline Intercept & Pillai's Trace & 0,996 & $4424,557^{\mathrm{b}}$ & 2,000 & 35,000 &, 000 \\
& Wilks' Lambda & 0,004 & $4424,557^{\mathrm{b}}$ & 2,000 & 35,000 &, 000 \\
& Hotelling's Trace & 252,832 & $4424,557^{\mathrm{b}}$ & 2,000 & 35,000 &, 000 \\
& Roy's Largest Root & 252,832 & $4424,557^{\mathrm{b}}$ & 2,000 & 35,000 &, 000 \\
\hline Kelompok & Pillai's Trace & 0,441 & 3,396 & 6,000 & 72,000 &, 005 \\
& Wilks' Lambda & 0,564 & $3,869^{\mathrm{b}}$ & 6,000 & 70,000 &, 002 \\
& Hotelling's Trace & 0,764 & 4,331 & 6,000 & 68,000 &, 001 \\
& Roy's Largest Root & 0,752 & $9,028^{\mathrm{c}}$ & 3,000 & 36,000 &, 000 \\
\hline
\end{tabular}

Berdasarkan Tabel 12 di atas, bahwa nilai signifikasi dari Wilks Lambda menunjukkan hasil 0,002 yang berarti nilai sig $<0,05$ dan dapat disimpulkan terdapat perbedaan peningkatan power otot tungkai dan kelincahan dari tiga bentuk latihan yang dijadikan fokus penelitian dan kelompok kontrol. Jadi dapat disimpulkan adanya perbedaan peningkatan dari power otot tungkai dan kelincahan antar kelompok pada keempat kelompok tersebut. Selanjutnya bisa dilihat kelompok mana saja yang dengan uji Pos Hoc Multiple Comparation dengan SPSS 22.

Setelah dapat dipastikan bahwa terdapat perbedaan yang signifikan antara ketiga jenis latihan dan kelompok kontrol, selanjutnya dengan uji lanjut Post Hoc Comparisons dengan analisis Least Significant Difference (LSD) yang digunakan untuk mengetahui kelompok manakah yang Jurnal IImiah Mandala Education memberikan perbedaan pengaruh yang lebiih besar dari segi peningkatannya antara ketiga jenis latihan dan kelompok kontrol. Adapun dasar pengambilan keputusan, yaitu a) peluang terjadinya kesalahan $\alpha=0.05$, b) Ho diterima atau Ha ditolak, jika nilai signifikansi $>0.05$, maka tidak terdapat kombinasi perbedaan yang signifikan antara ketiga latihan, c) Ha diterima atau Ho ditolak, jika nilai signifikansi $<0.05$, maka terdapat kombinasi perbedaan yang signifikan antara ketiga latihan.

Tabel 13. Uji Pos Hoc LSD

\begin{tabular}{|c|c|c|c|c|c|}
\hline \multirow{2}{*}{\multicolumn{2}{|c|}{ Kelompok }} & \multicolumn{2}{|c|}{ Power } & \multicolumn{2}{|c|}{ Kelincahan } \\
\hline & & \multirow{2}{*}{$\begin{array}{c}\begin{array}{c}\text { Mean } \\
\text { Difference }\end{array} \\
33,6080^{\circ}\end{array}$} & \multirow{2}{*}{$\begin{array}{c}\text { Sig. } \\
0,047\end{array}$} & $\begin{array}{c}\text { Mean } \\
\text { Difference }\end{array}$ & $e^{\text {Sig. }}$ \\
\hline \multirow[t]{3}{*}{ Cone Hop With 180 Degree Turn } & Lateral Jump Over Barrier & & & $-.5950^{*}$ & 0,046 \\
\hline & Lateral Cone Hops & 19,5963 & 0,239 & -1930 & 0,507 \\
\hline & Kontrol & $43,9919^{\prime \prime}$ & 0,011 & $-1,0420^{\prime \prime}$ & " 0,001 \\
\hline \multirow[t]{2}{*}{ Lateral Jump Over Barrier } & Cone Hop With 180 Degree Turn & $-33,6080^{*}$ & 0,047 &, $5950^{*}$ & 0,046 \\
\hline & $\begin{array}{l}\text { Lateral Cone Hops } \\
\text { Kontrol }\end{array}$ & $\begin{array}{l}-14,0117 \\
10,3839\end{array}$ & $\begin{array}{l}0,398 \\
0,530\end{array}$ &, 4020 & $\begin{array}{l}0,171 \\
0,129\end{array}$ \\
\hline \multirow[t]{2}{*}{ Lateral Cone Hops } & Cone Hop With 180 Degree Turn & $-19,5963$ & 0,239 & 1930 & 0,507 \\
\hline & $\begin{array}{l}\text { Lateral Jump Over Barrier } \\
\text { Kontrol }\end{array}$ & $\begin{array}{l}14,0117 \\
24,3955\end{array}$ & $\begin{array}{l}0,398 \\
0,145\end{array}$ & $\begin{array}{l}-, 4020 \\
-, 8490^{*}\end{array}$ & $\begin{array}{l}0,171 \\
0,006\end{array}$ \\
\hline \multirow[t]{3}{*}{ Kontrol } & Cone Hop With 180 Degree Turn & $-43,9919^{*}$ & 0,011 & $1,0420^{*}$ & 0,001 \\
\hline & Lateral Jump Over Barrier & $-10,3839$ & 0,530 & ,4470 & 0,129 \\
\hline & Lateral Cone Hops & $-24,3955$ & 0.145 & $.8490^{*}$ & 0,006 \\
\hline
\end{tabular}

Pada tabel 13 berdasarkan hasil Mean difference Uji Pos Hoc antar kelompok posttest, pada variabel power kelompok Cone Hop Witth 180 Degree turn terlihat lebih dominan peningkatannya atau signifikan dalam efek Lateral Jump Over Barrier dan kelompok kontrol, hasil mean defferent sebesar 33,6080 kelompok Cone hop with 180 degree turn dan nilai signifikasi yaitu 0,047 di variabel power lebih besar dibandingkan dengan kelompok lainnya. Sedangkan pada variabel kelincahan kelompok Cone hop with 180 degree turn juga mempunyai nilai yang signifikan perbedaannya dalam hal peningkatan kelincahan sebesar 0,046 dibandingkan dengan kelompok Lateral Jump Over Barrier, Lateral Cone Hop, dan kelompok kontrol. Jadi dapat disimpulkan bahwa kelompok Cone Hop Witth 180 Degree turn memiliki peningkatan yang lebih besar dibandingkan dengan kelompok lainnya, dari segi gerakan kelompok ini memiliki gerakan kombinasi lompatan dan perubahan putaran di udara seketika, sehingga dapat memberi efek pada perkembangan komponen fisik power dan kelincahan.

Penggunaan Plyometric telah banyak digunakan untuk meningkatkan kinerja pergerakan otot yang dinamis, kinerja otot seperti kemampuan melompat vertikal, kecepatan, kelincahan, dan aktivasi otot 
ekstremitas bawah (Sosbir, 2016). Latihan tipe seperti ini sudah terdapat pada gerakan Cone Hop With 180 Degree Turn. Pada gerakannya dilakukan dengan kuat dan cepat, sehhingga pada fase awalan melakukan lompatan, langsung melakukan putaran di udara 180 derajat, dan mendarat untuk langsung melakukannya lagi secara berulang-ulang dilakukan dengan pijakan kaki, fungsi sendi dan otot tungkai saat mendarat dengan kuat berpengaruh pada otot tungkai. Perpindahan dan perputaran 180 derajat di udara secara cepat akan berefek pada dua komponen biomotor yaitu power otot tungkai dan kelincahan. Hal ini sesuai dengan karalteristik gerak power. Menurut Mylsidayu dan Kurniawan, (2015, p. 138) bentuk dan karakteristik power selalu bersifat eksplosive yang mana irama dan gerakannya cepat yang berarti saat pelaksanaan memerlukan kecepatan dan kekuatan.

Setelah dilakukan latihan selama delapan minggu dengan menggunakan latihan Plyometric Cone Hop With 180 Dgree Turn terdapat peningkatan dari sebelum dilakukan pelatihan (Pretest) dan sesudah (Postest). Pada penelitian Sudhakar, et.al (2016) hasil penelitiannya yang terdapat jenis latihan Cone Hop With 180-Degree Turn, menunjukkan bahwa pelatihan plyometric menguntungkan untuk mengembangkan power tubuh bagian bawah dan kelincahan karena meningkatkan kemampuan subjek untuk memanfaatkan elastiasitas saraf dari sik; us pemendekan dan peregangan otot. Bahkan pelatihan Plyometric dapat digunakan untuk pemula atau non- atlet, Pada penelitian Aalizadeh (2015) pelatihan Plyometric mampu meningkatkan Sprint, Power dan kelincahan pada peserta Non Atlet.

Lateral Lateral Jump over barrier memiliki karakteristik yang berbeda dengan bentuk latihan yang lainnya, pergerakannya yang lebih simple dan dinamis dengan hanya menggunakan satu Cone atau Gawang. Pada dasarnya dari segi prinsip gerakan dan sifatnya sama dengan yang lainnya yaitu melibatkan proses eccentric dan concentric otot. Latihan ini pada dasarnya menuntut bagian tubuh manusia melakukn kontraksi secara terus menerus pada otot dengan melompati penghalang berupa cone setinggi $30 \mathrm{~cm}$ Jurnal Ilmiah Mandala Education sehingga bisa meningkatkan komponen power otot tungkai. Power sendiri terdiri dari dua arah jenis, yaitu Explosive power dan Strength Power tergantung dari bagaimana karakteristik gerakannya. Pada gerakan Lateral Jump Over Barrier dilakukan dengan irama yang cepat di setiap pijakan dan perubahan geraknya dari tahap mendarat dan lompatan melewati cone dilakukan dengan kuat, cepat, seketika tanpa adanya jeda setiap setnya, sehingga menghasilkan irama gerakan yang stabil dan ini mampu mempengaruhi perkembangan komponen biomotor power dan kelincahannya. Hal ini juga diperkuat apa yang diungkapkan Harsono (1986. P.47) yaitu terdapat dua unsur penting dalam dalam daya ledak atau Power; a) kekuatan otot dan b), kecepatan dalam mengerahkan tenaga maksimal. Maka dari itu karakteristik geraknya harus dilakukan dengan kuat dan cepat.

Perlakuan pemberihan latihan Lateral Jump Over Barrier dilakukan selama 8 minggu yang mana setiap 2 minggu meningkatkan level intensitasnya karena dalam waktu 2 minggu itulah tubuh secara fisiologis akan beradaptasi pada intensitas latihan yang ada. Latihan ini berarti cukup efektif diterapkan untuk meningkatkan komponen biomotor dengan fokus dalam penelitian ini dua komponen Power dan kelincahan. Pelatihan Lateral Jump Over Barrier dapat diterapkan pada cabang olahraga tertentu seperti salah satunya permainan Bola Basket yang membutuhkan komponen fisik seperti power, kelincahan, dan komponen lainnya.

Latihan harus menyesuaikan dengan kondisi dan kemampuan setiap individu, Plyometric yang dikembangkan Chu (2013, p. 40 ) juga menuturkan menurutnya pendidikan dan pengajaran Plyometric yang tepat sangat penting untuk keamanan, efektif, dan menyenangkan pelatihan plyometric. Diperlukan pendidikan yang sesuai usia dan instruksi yang berkualitas agar berhasil mengintegrasikan berbagai komponen yang berkaitan dengan penguasaan gerakan dasar, variasi latihan, perkembangan latihan, dan pemulihan yang terstruktur. Pada penelitian Chikhalkar et.al (2018) dalam penelitiannya 
yang dilakukan sealam 6 minggu, menyebutkan bahwa pelatihan Plyometric memiliki efek posistif pada kinerja Vertical Jump (Power), kinerja kelincahan dan kecepatan hal ini terjadi dikarenakan bentuk latihan plyometric yang memanfaatkan peregangan dan pemendekan memberikan stimulus reflek penyimpanan energi untuk memfasilitasi peningkatan otot secara maksimal.

Sesuai dengan ciri khas metode plyometric Streach Shortening Cycle (SSC). Menurut Chu (2013, p.4) sinergi otot-otot ketika bertransisi melalui masing-masing tindakan otot (eksentrik,isometrik, konsentris). Sifat gerakan Plyometric yang melibatkan kontraksi otot memanjang dan memendek secara cepat, kuat dan program latihan yang progresif sehingga mampu meningkatkan komponen biomotor power, tentunya diarenakan iramanya yang cepat dan kuat maka bisa ke arah jenis power explosive. Hal ini juga berpengaruh pada unsur kelincahan yang di dapat dari bentuk latihan, karakteristik gerakan dan irama gerakan yang cepat dan kuat.

Latihan ini secara fisiologis merupakan hasil kinerja dari stimulus yang diberikan dan diterima dengan baik oleh sistem syaraf ysng dikirimkan kepada otot untuk merespons dan harus dilakukan dengan mengimbangi perpindahan arah dan lompatan secara cepat, Unsur gerakan Lateral Cone Hops yang dilakukan dengan melompat melewati beberapa cone yang berjajar menyamping dan dari segi teknisnya terdapat perubahan arah yang cepat setelah fase lompaatan lalu kaki mendarat untuk langsung melompat lagi ke cone selanjutnya, dan pada saat cone terakhir langsung bertolak merubah arah kembali melewati cone. Hal ini karena pada prinsipnya kelincahan adalah pergerakannya dapat mengubah arah dengan cepat. Pada penelitian Harmandeep, et.al (2015) metode latihan plyometric yang terdapat bentuk latihan lateral cone hops mampu meningkatkan daya ledak (power) otot tungkai sehingga secara otomatis mampu meningkatkan tingginya lompatan. Penelitian dari (Hayyun, 2016) terdapat peningkatan daya ledak otot tungkai dan kelincahan pada kelompok Front Cone Hop Jurnal Ilmiah Mandala Education dan kelompok Lateral cone hops setelah diberikan latihan. Selain itu, terdapat perbedaan pengaruh antara ketiga kelompok dilihat dari peningkatan daya ledak otot tungkai dan kelincahan.

Hasil analisis dengan bentuk latihan Lateral Cone Hops didapatkan hasil bahwa latihan tersebut memiliki pengaruh terhadap Power otot tungkai dan kelincahan. Latihan Lateral Cone Hops juga dapat digunakan di cabang olah raga yang memiliki gerak dasar kompleks yang membutuhkan power dan kelincahan seperti Volley, Sepak Bola, Badminton, Atletik dll.

Pemberian latihan Plyometric dilakukan progam latihan jangka pendek dan progresif dengan pengawasan dari segi teknik latihan, intensitas yang diberikan, irama latihan akan mampu memberikan hasil yang lebih baik. Hal tersebut diperkuat oleh penelitian Aalizadeh (2015), pelatihan Plyometric jangka pendek efektif meningkatkan sprint, kekuatan, power, dan kelincahan. Pada penelitian ini, dilakukan pemberian perlakuan selama 8 minggu menunjukkan hasil dari uji Manova menunjukkan terdapat perbedaan pengaruh antara ketiga bentuk latihan tersebut. Signifikansi kelompok menggunakan post hoc test juga menyatakan bahwa treatment latihan Cone hop with 180-degree turn dapat memberikan hasil peningkatan yang lebih besar dari pada latihan Lateral Jump Over Barrier, dan Lateral Cone Hops pada variabel power, Sedangkan pada variabel kelincahan hasil signifikansi uji Pos Hoc juga menunjukkan bahwa terdapat peningkatan yang lebih besar pada kelompok Cone hop with 180-degree turn daripada kelompok lainnya. Meskipun dari segi sarana cone yang digunakan berukuran sama yakni $30 \mathrm{~cm}$, namun dari segi gerakannya dua kelompok ini memiliki gerakan yang berbeda. Latihan Cone hop with 180-degree turn memiliki gerakan kombinasi yang lebih kompleks, yaitu lompatan dan perubahan putaran 180 derajat di udara seketika dan secara konstan dilakukan dengan irama yang cepat di setiap perpindahan dan perubahan gerakan memutar 180 di udara dengan cepat dan pijakan yang kuat, sehingga dapat memberi efek pada perkembangan 
komponen fisik power otot tungkai dan kelincahan.

Pada kelompok Lateral Jump Over Barrier dari segi gerakannya yaitu melompati satu cone setinggi $30 \mathrm{~cm}$ dengan menyamping ke kanan dan ke kiri secara berulang-ulang. Sedangkan Lateral Cone hop dari segi gerakan melompati cone setinggi $30 \mathrm{~cm}$ menyamping sebanyak 5 Cone dengan irama yang cepat dan pijakan yang kuat sehingga menghasilkan perkembangan pada komponen power dan kelincahan. Pada saat melakukan latihan Cone Hop With 180-degree turn, Lateral jump vver Barrier, dan Lateral Cone hops beban pada otot tungkai akan bertambah. Faktor variasi gerakan, irama dan alat yang digunakan akan mempengaruhi hasil peningkatan pada komponen biomotor power otot tungkai dan kelincahan. Peran power sangat penting, karena seiring dengan perkembangannya akan mempengaruhi komponen biomotor lainnya terutama kelincahan yang merupakan bagian dari kecepatan. Menurut Bucher (2009, p.206) besarnya kekuatan berbanding lurus dengan kecepatan, artinya jika kekuatan dan kecepatan semakin besar maka akan menghasilkan power yang lebih besar. Pada tiga bentuk latihan ini secara khusus memiliki perkenaan atau sasaran otot yang sama. Menurut Chu (2013, p. 21) terdapat tujuh sasaran kelompok otot pada tubuh bagian bawah yaitu; otot Gluteus muscle groups, hip flexor gruoup, quadriceps muscle groups, hamstring muscle groups, gastrocnemius, anterior tibialis, dan abdominal.

Maka dapat direkomendasikan kepada pelatih, siswa, atlit dan praktisi olahraga pada umumnya dan khususnya pemula, olahragawan remaja berusia 16-17 tahun, bahwa pelatihan Cone hop with 180-degree turn, Lateral jump over Barrier, Lateral cone hops tepat dalam meningkatkan kemampuan Power dan kelincahan. Sedangkankan kesimpulan dalam perbandingan rata-rata antar kelompok bahwa kelompok Cone hop with 180-degree turn lebih memberikan hasil yang lebih besar dari pada kelompok lainnya.

\section{KESIMPULAN}

Berdasarkan hasil penelitian dan pembahasan yang diuraikan pada -bab Jurnal Ilmiah Mandala Education sebelumnya, maka dapat ditarik beberapa kesimpulan penelitian sebagai berikut;

1. Terdapat pengaruh yang signifikan latihan Cone Hop with 180-Degree Turn, terhadap peningkatan power otot tungkai sebesar 17 $\%$ pada siswa kelas XI SMA Negeri 1 Batuan Sumenep

2. Terdapat pengaruh yang signifikan latihan Lateral Jump Over Barrier, terhadap peningkatan power otot tungkai sebesar 5 $\%$ pada siswa kelas XI SMA Negeri 1 Batuan Sumenep

3. Terdapat pengaruh yang signifikan latihan Lateral Cone Hops, terhadap peningkatan power otot tungkai sebesar $10 \%$ pada siswa kelas XI SMA Negeri 1 Batuan Sumenep?

4. Terdapat pengaruh yang signifikan latihan Cone Hop with 180 Degree Turn, terhadap peningkatan kelincahan sebesar $11 \%$ pada siswa kelas XI SMA Negeri 1 Batuan Sumenep.

5. Terdapat pengaruh yang signifikan latihan Lateral Jump Over Barrier, terhadap peningkatan kelincahan sebesar $6 \%$ pada siswa kelas XI SMA Negeri 1 Batuan Sumenep.

6. Terdapat pengaruh yang signifikan latihan Lateral Cone Hops, terhadap peningkatan kelincahan sebesar $8 \%$ pada siswa kelas XI SMA Negeri 1 Batuan Sumenep.

7. Berdasarkan Uji Manova terdapat perbedaan pengaruh latihan antar kelompok Plyometric Cone Hop With 180Degree Turn, Lateral Jump Over Barrier, Lateral Cone Hop terhadap peningkatan power otot tungkai dan kelincahan pada siswa putra kelas XI SMA Negeri 1 Batuan Sumenep. Dalam hal ini Latihan Plyometric Cone Hop With 180 Degree Turn memiliki pengaruh yang lebih besar (signifikan) terhadap power otot tungkai. Hal ini juga yang terjadi pada varibel keliancahan yang mana Latihan Plyometric Cone Hop With 180 Degree Turn memiliki pengaruh yang lebih besar (signifikan) peningkatannya terhadap kelincahan.

\section{REFERENSI}

Abade E., Sampaio J, Goncealves B., Baptista1 J., Alves A,.Viana J,. (2017). Effect of Different Re-Warm Up Activities in 
Football

Players

Performance.Reseaarch Center in

Sport, Health Science and Human

Development, CIDESD,12(6): 1-13.

Bompa Tudor O., Haff Gregory G. (2009).

Periodization Theory and

Methodology of training. USA:

Human Kinematics

Bompa Tudor O., Buzzichelli Carlo.(2015).

Periodization Training for Sport. Third

Edition. United States: Human

Kinetics

Bucher, Charles A. and Haff G. 2009. Physical Education, Exercise, Science, and Sport. New York: MC Graw Hill

Chu, Donald, A., Myer Gregory D. (2013).Dynamic Strength and Explosive Power. USA: Human Kinetics

Chikhalkar, Sharvari.,Ghodey Sukhada., Ghodey Snehal. Effect of Plyometric Training on Speed, Power, and Agility in adolescents Playing Basketball. International Journal of Allied Medical Sciences and Clinical Research (IJAMSCR). ISSN: 2347-6567. Volume 6. Issue2, Apr-Jun- 2018.

Derek, Hansen., Steve Kennelly. (2017). Plyometric Anatomy.USA: Human Kinetics

Elsayed, Mohammed, (2012). Effect of Plyometric Training on specific Phisical Abilities in Long Jump Athletes.World Journal of Science Sport.Vol.7 No.2. Pp. 105-108

Giriwijoyo, Santosa. Sidik, Zafar, D. (2012). Ilmu Faal Olahraga (Fisiologi Olahraga). Bandung. PT Remaja Rosdakarya.

Hartono., S. Kusnanik N.W., Nasution J. (2016) Dasar-dasar Fisiologi Olahraga. Surabaya. Unesa University Press.

Harsono. 1986. Ilmu Coaching. Jakarta: Pusat Ilmu Olahraga KONI Pusat

Harsono (1988). Coaching dan Aspek-Aspek Psikologis dalam Coaching. Jakarta: Depertemen Pendidikan dan Kebudayaan Dirjendikti.

Harmandeep. S., Satinder. K., Amita. R., Anupriya S. (2015). Effect of Six-
Week Plyometric on Vertical Jumping Ability of Volleyball Players. Research Journal of Physical Education Science. ISSN 2320-9011. Vol. 3 (4), 1-4

Jain, Aashish, Kumar., Tiwari, M. et al. (2015).The Effect of Six Weeks Plyometric Training on Agility in Male Basketball Players.International Journal of Therapies and Rehabilitation Research. ISSN: 22780343. 2015; 4 (4): 183-190

Kumar Raj. (2013). The Effect of 6 Week Plyometric Training program on Agility of Collegiate Soccer Players. International Jornal of Behavioral Social and Movement Secience. ISSN: 2277-7574. Vol 02.Issues 01. Pp 170176.

Lhaksana. (2011). Taktik \& Strategi Futsal Modern. Jakarta: Penebar Swadaya Group

Maksum, A. (2012) Metodologi Penelitian dalam Olahraga. Surabaya: FIK Universitas Negeri Surabaya

Mathisen, EG.(2014). Effect of High Speed and Plyometric Training for 13 Year Old Male Soccer Players on Acceleration and Agility Performance.Lase Journal of Sport Science 2014/5/2. Departement of Sport Siences.UiT, the Norwegia Artic University.

Mannan, S. Johnson, P. Avulalah, N. Nathaniel, S. (2015) Study on Specific Plyometric Training On Speed Power and Agility of Male Volleyball Players. JournalSicience of Sport Training. ISS : 2394-9724. Vol. 02. Supplementary issue e. 2015

Mylsidayu, A \& Kurniawan F. (2015). Ilmu Kepelatihan Dasar. Bandung: Alfabeta.

Nala.( 2011). Prinsip Pelatihan Fisik Olahraga. Denpasar: Universitas Udayana.

Nurhasan. (2011). Tips Praktis Menjaga Kebugaran Jasmani. Gresik: Abil Pustaka.

Radcliffe, James \& Farentinos, Robert. (1985). Plyometrics Explosive Power 


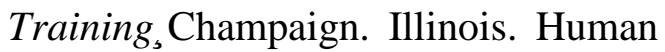

Kinetics Plublishers. Inc.

Ratamess, Nicholas. (2012). ACSM's Foundations of Strength Trainingand conditioning. Indianapolis. Lippincot Williams \& Wilkins.

Sukadiyanto dan Dangsina Muluk.(2011). Pengantar Teori dan Metodologi Melatih Fisik.Bndung. Alfabeta

Sugiyono. (2011). Metode Penelitian Kuantitatif, Kualitatif dan $R \& D$. Bandung: Afabeta.

Sugiyono. (2015). Meode Penelitian Kombinasi (Mix Methods). Bandung: Alfabeta

Sudhakar. S., G. Kumar M., Ramanathan K.., Vasanth. 2016. Efficacy of 6 Week Plyometric Training on Agility Performance in Collegiate Male Basketball Players. ISSN(P): Applied;ISSN(E): 2455-1996. Vol 2, Issue 2, Dec 2016, 1-8

Taheri,E,.Niksersht.Khosnam, E.(2014). The effect of 8 weeks of plyometric and resistance training on agility, speed and explosive power in soccer players.Journal International. ISSN: 2248 - 9216. Euro. J. Exp. Bio., 2014, 4 (1): 383-386.

Vaczi, M. Tollar, J., Meszler., Juhasz, T., Karsai,I. 2013. Short-Term High Intensity Plyiometric Training Program Improves Strength, Power and Agility in Male Soccer Player. Journal of Human Kinetic. Vol. 36/2013, 17-26.

Widiastuti, (2011). Tes dan Pengukuran Olahraga. Jakarta: PT, Bumi Jaya.

Yiannis, M. (2014). Plyometric training progam for young soccer players: a review.International Journal of Sport Studies. ISSN: 2251-7502. Vol., (4 (12), 1455-1461. 